University of Nebraska - Lincoln

DigitalCommons@University of Nebraska - Lincoln

$4-2021$

\title{
Observational and Modeling Analysis of Land-Atmosphere Interactions over Adjacent Irrigated and Rainfed Cropland During the GRAINEX Field Campaign.
}

Eric Rappin

Rezaul Mahmood

Udaysankar S. Nair

Roger A. Pielke Sr.

Follow this and additional works at: https://digitalcommons.unl.edu/natrespapers

Part of the Natural Resources and Conservation Commons, Natural Resources Management and Policy Commons, and the Other Environmental Sciences Commons

This Article is brought to you for free and open access by the Natural Resources, School of at DigitalCommons@University of Nebraska - Lincoln. It has been accepted for inclusion in Papers in Natural Resources by an authorized administrator of DigitalCommons@University of Nebraska - Lincoln. 
EGU21-13385

https://doi.org/10.5194/egusphere-egu21-13385

EGU General Assembly 2021

(c) Author(s) 2021. This work is distributed under

the Creative Commons Attribution 4.0 License.

\title{
Observational and Modeling Analysis of Land-Atmosphere Interactions over Adjacent Irrigated and Rainfed Cropland During the GRAINEX Field Campaign.
}

\author{
Eric Rappin ${ }^{1}$, Rezaul Mahmood ${ }^{2}$, Nair Udaysankar ${ }^{3}$, and Roger Pielke Sr. ${ }^{4}$ \\ ${ }^{1}$ Western Kentucky University, United States of America (eric.rappin@wku.edu) \\ ${ }^{2}$ University of Nebraska - Lincoln \\ ${ }^{3}$ University of Alabama - Huntsville \\ ${ }^{4}$ Cooperative Institute for Research in Environmental Sciences (CIRES) at the University of Colorado Boulder
}

Continued scientific study has revealed that land use and land cover change play a key role in climate and that the application of irrigation is an important biogeophysical contributor to climate modification across spatial scales. The Great Plains Irrigation Experiment (GRAINEX) was conducted in the spring and summer of 2018 to investigate Land-Atmosphere interactions just prior to and through the growing season across adjacent, but distinctly unique, soil moisture regimes (contrasting irrigated and rainfed fields). GRAINEX was uniquely designed for the development and analysis of an extensive observational dataset for comprehensive process studies of Land-Atmosphere interactions, by focusing on irrigated and rainfed croplands in a 100 $\times 100 \mathrm{~km}$ domain in southeastern Nebraska. Observation platforms included multiple NCAR EOL Integrated Surface Flux Systems and Integrated Sounding Systems, NCAR CSWR Doppler Radar on Wheels, 1200 radiosonde balloon launches from 5 sites, the NASA GREX airborne L-Band radiometer, and 75 University of Alabama-Huntsville Environmental Monitoring Economic Monitoring Sensor Hubs (EMESH mesonet stations). The presentation will provide an overview of the field campaign, the dataset collected, and investigate the contrast of L-A intractions across an irrigation gradient through observations and mesoscale/microscale modeling on timescales ranging from the diurnal to the seasonal. Attention will be given to how variations in the land surface state, as a function of irrigation fraction, impacts near-surface meteorology and atmospheric boundary layer evolution at local and regional scales.

Citation: Rappin, E., Mahmood, R., Udaysankar, N., and Pielke Sr., R.: Observational and Modeling Analysis of Land-Atmosphere Interactions over Adjacent Irrigated and Rainfed Cropland During the GRAINEX Field Campaign., EGU General Assembly 2021, online, 19-30 Apr 2021, EGU21-13385, https://doi.org/10.5194/egusphere-egu21-13385, 2021. 